\title{
Synthesis and Characterization of $\alpha_{v} \beta_{3}$-Targeting Peptidomimetic Chelate Conjugates for PET and SPECT Imaging
}

\author{
Young-Seung Kim ${ }^{a}$, Kido Nwe ${ }^{a}$, Diane E. Milenic ${ }^{a}$, Martin W. Brechbiel ${ }^{a}$, Stanley Satz ${ }^{b}$, and \\ Kwamena E. Baidoo ${ }^{a,{ }^{*}}$ \\ aRadioimmune \& Inorganic Chemistry Section, $\mathrm{ROB}, \mathrm{NCI}, \mathrm{NIH}$, Bethesda, Maryland, USA \\ ${ }^{b}$ Advanced Imaging Projects, Inc., Doral, Florida, USA
}

\section{Abstract}

There is growing interest in small peptidomimetic $a_{v} \beta_{3}$ integrin antagonists that are readily synthesized and characterized and can be easily handled using physiological conditions. Peptidomimetic 4-[2-(3,4,5,6-tetrahydropyrimidine-2-ylamino)ethyloxy]benzoyl-2-[N-(3-aminoneopenta-1-carbamyl)]-aminoethylsulfonyl-amino- $\beta$-alanine (IAC) was successfully conjugated to 1-(1-carboxy-3-carbo-t-butoxypropyl)-4,7-(carbo-tert-butoxymethyl)-1,4,7-triazacyclononane $\left(\operatorname{NODAGA}(t \mathrm{Bu})_{3}\right)$ and 1-(1-carboxy-3-carbotertbutoxymethyl)-1,4,7,10-tetraazacyclododecane $\left(\operatorname{DOTAGA}(t \mathrm{Bu})_{4}\right)$ and radiolabeled with ${ }^{111} \mathrm{In},{ }^{67} \mathrm{Ga}$ and ${ }^{203} \mathrm{~Pb}$. Results of a radioimmunoassay demonstrated binding to purified $\alpha_{v} \beta_{3}$ integrin when one to four equivalents of integrin were added to the reaction. Based on this promising result, investigations are moving forward to evaluate the NODA-GA-IAC and DOTA-GA-IAC conjugates for the targeting tumor associated angiogenesis and $a_{v} \beta_{3}$ integrin positive tumors to define their PET and SPECT imaging qualities as well as their potential for delivery of therapeutic radionuclides.

\section{Keywords}

Integrin $a_{v} \beta_{3}$; NODAGA; DOTAGA; Peptidomimetics; antagonist; ${ }^{68} \mathrm{Ga} ;{ }^{203} \mathrm{~Pb}$; PET imaging; SPECT imaging

\begin{abstract}
Integrins are a family of transmembrane glycoproteins with associated $\alpha$ and $\beta$ subunits forming 25 unique heterodimers that facilitate adhesion and migration of cells on the extracellular matrix proteins found in intercellular spaces and basement membranes. ${ }^{1}$ One of these integrins, $a_{v} \beta_{3}$ integrin, interacts with vitronectin, fibronectin, fibrinogen, thrombospondin, collagen, laminin and von Willebrand factor. This integrin is overexpressed in tumor induced angiogenic vessels and in various human tumors, but is found at low levels on epithelial and endothelial cells. It is therefore a widely recognized target for the development of molecular probes for imaging angiogenesis and cancer therapy. Towards this end, the tumor imaging capability of several RGD peptides that act as $\alpha_{v} \beta_{3}$ integrin
\end{abstract}

\footnotetext{
*To whom correspondence should be addressed: Kwamena E. Baidoo, Radioimmune \& Inorganic Chemistry Section, Radiation Oncology Branch, NCI, NIH, 10 Center Drive, MSC-1002, Rm B3B69, Bethesda, Maryland 20892-1002, USA. Phone: 301-496-6494; Fax 301-402-1923; baidook@mail.nih.gov.

Publisher's Disclaimer: This is a PDF file of an unedited manuscript that has been accepted for publication. As a service to our customers we are providing this early version of the manuscript. The manuscript will undergo copyediting, typesetting, and review of the resulting proof before it is published in its final citable form. Please note that during the production process errors may be discovered which could affect the content, and all legal disclaimers that apply to the journal pertain.

Supplementary data Materials and methods, general synthesis and radiolabeling conditions are provided. Supplementary data associated with this article can be found, in the online version.
} 
antagonists has been demonstrated by several research groups. Additionally, several of these peptides have been shown to inhibit tumor angiogenesis and interrupt metastasis in many models. ${ }^{2-4}$

There is growing interest in peptidomimetic $\alpha_{v} \beta_{3}$ integrin antagonists composed of a stable core scaffold with basic and acidic groups that mimic the guanidine and carboxylate pharmacophore of RGD peptides. Peptidomimetics tend to have higher activity, specificity and longer duration of action compared to the peptides. One such peptidomimetic $a_{v} \beta_{3}$ integrin antagonist, 4-[2-(3,4,5,6-tetrahydropyrimidine-2-ylamino)ethyloxy]benzoyl-2aminoethylsulfonyl-amino- $\beta$-alanine (IA) was synthesized by Hood et al. ${ }^{5}$ Subsequent, modification of IA to the corresponding carbamate derivatives by the Danthi group resulted in 4-[2-(3,4,5,6-tetrahydropyrimidine-2-ylamino)ethyloxy]benzoyl-2-[N-(3-aminoneopenta-1-carbamyl)]-aminoethylsulfonyl-amino- $\beta$-alanine (IAC), with a binding affinity 20 times greater than that of IA. ${ }^{6}$ A SPECT (single photon emission computed tomography) imaging study with ${ }^{111}$ In-DOTA-Bz-SCN- IAC was also performed and tumor was clearly visualized at $4 \mathrm{~h}$ p.i. ${ }^{7111}$ In-DOTA-Bz-SCN- IAC was prepared using the bifunctional chelate DOTA-Bz-SCN which differs from the DOTA-GA described in this study.

Clinically, SPECT and PET (positron emission tomography) play significant roles allowing noninvasive imaging of internal physiological and biochemical function and pathologies in vivo. While PET is more expensive, it has significant advantages over SPECT with respect to its ability to better quantify images. Of metallic radionuclides currently being investigated for PET applications, gallium-68 $\left({ }^{68} \mathrm{Ga}\right)$ has grown in popularity. ${ }^{8,} 9$ The popularity of ${ }^{68} \mathrm{Ga}$ stems from the ease of on site production from a long lived generator system $\left({ }^{68} \mathrm{Ge} /{ }^{68} \mathrm{Ga}\right)$ rather than a cyclotron, and automation for incorporation into radiolabeled compounds. ${ }^{10}$ The 67.7 min half-life of ${ }^{68} \mathrm{Ga}$ is an appropriate match to the biological half-lives of peptides. Gallium(III) typically binds with chelates possessing multiple anionic oxygen donors preferring a coordination number of six in an octahedral geometry. Fitting these preferences, the macrocyclic ligand, 1,4,7-triazacyclononane-1,4,7-triacetic acid (NOTA), is well established as forming very stable complexes with a wide variety of metals, $\mathrm{Ga}$ (III) being one of them. ${ }^{11}$ Several NOTA derivatives have been reported (Figure 1) for use in the radiolabeling of proteins and peptides. Recently, Knetsch et al reported a ${ }^{68} \mathrm{Ga}$-labeled NODA-GA-conjugated RGD peptide ([ $\left.{ }^{68} \mathrm{Ga}\right]$ NODAGA-RGD) that showed better tumor to blood ratio in vivo than the corresponding $\left[{ }^{68} \mathrm{Ga}\right]$ DOTA-RGD derivative. ${ }^{12}$

While interest in ${ }^{68} \mathrm{Ga}$ for PET imaging is currently significant, there are $\mathrm{Pb}(\mathrm{II})$ isotopes that have also been of interest for biomedical applications. Specifically, ${ }^{203} \mathrm{~Pb}$ and ${ }^{212} \mathrm{~Pb}$ are radiometals possessing favorable properties for use in nuclear medicine for potential diagnostic and therapeutic applications, respectively. ${ }^{13-21203}$ Lead $\left(\mathrm{t}_{1 / 2}=51.9 \mathrm{~h}\right)$ emits a $\gamma$ ray $(279 \mathrm{keV})$ that is ideal for single photon emission computed tomography (SPECT) imaging and is suitable for pharmacokinetic and pharmacodynamic tracer studies. In addition, ${ }^{203} \mathrm{~Pb}$ can serve as one half of a potential matched-pair of radioisotopes when combined with ${ }^{212} \mathrm{~Pb}$ for therapeutic applications. ${ }^{212} \mathrm{Lead}\left(\mathrm{t}_{1 / 2}=10.6 \mathrm{~h}\right)$ has been studied as an 'in vivo generator' of ${ }^{212} \mathrm{Bi}\left(\mathrm{t}_{1 / 2}=60 \mathrm{~min}\right)$ to overcome the short half-life of that daughter isotope. The macrocyclic polyaminocarboxylate chelate DOTA, $(1,4,7,10-$ tetraazacyclododecane-N,N',N",N"'-tetraacetic acid labeled with ${ }^{212} \mathrm{~Pb}$ provides a complex that is adequately stable in vivo to sequester the radionuclide. ${ }^{17}$

The Mäcke group in Switzerland have synthesized a DOTA derivative analogous to NOTAGA, , 1-(1-carboxy-3-carboterbutoxymethyl)-1,4,7,10-tetraazacyclododecane (DOTA$\left.\mathrm{GA}(t \mathrm{Bu})_{4}\right){ }^{22}$ The DOTA-GA $(t \mathrm{Bu})_{4}$ affords four intact carboxylic acid functional groups with a free carboxylate side chain ready for conjugation to the $N$-terminus of peptides which makes it useful for biomedical applications. 
In the present study, the objective was to move beyond the use of RGD peptides as delivery vectors to the various integrin targets and explore the utility of IAC for such applications. ${ }^{68}$ Gallium labeling was investigated for PET applications using NODA-GA and ${ }^{67} \mathrm{Ga}$ as a surrogate for ${ }^{68} \mathrm{Ga}$, and ${ }^{203} \mathrm{~Pb}$ for SPECT imaging using DOTA-GA. To this end, IAC was successfully conjugated to NODAGA (Scheme 1) and DOTA-GA (Scheme 2) and the conjugates were radiolabeled with ${ }^{111}$ In or ${ }^{67} \mathrm{Ga}$ for the NODA-GA conjugate and ${ }^{203} \mathrm{~Pb}$ for the DOTA-GA conjugate. In brief, NODA-GA $(t \mathrm{Bu})_{3}$ or DOTAGA $(t \mathrm{Bu})_{4}, N$ hydroxysuccinimide, and EDC were dissolved in dichloromethane and the reaction mixture was stirred for $24 \mathrm{~h}$. The mixture was extracted with saturated $\mathrm{NaCl}$ solution, $5 \% \mathrm{NaHCO}_{3}$, and saturated $\mathrm{NaCl}$ again. The organic layer was dried over $\mathrm{MgSO}_{4}$, filtered, and dried under vacuum resulting in the formation of yellowish oils $\mathbf{2}$ or $\mathbf{5}$. The IAC and $\mathbf{2}$ or $\mathbf{5}$ were combined in anhydrous DMF and diisopropylethylamine was added to the mixture which was then stirred overnight at room temperature. Reverse-phase HPLC purification followed by TFA deprotection yielded $\mathbf{1}$ or $\mathbf{4}$, respectively. ${ }^{23,24}$ To evaluate the radiolabeling efficiency of the NODA-GA and DOTA-GA conjugates, ${ }^{111} \mathrm{In},{ }^{67} \mathrm{Ga}$ and ${ }^{203} \mathrm{~Pb}$ were employed to demonstrate facile formation of complexes with these radionuclides. The NODA-GA conjugate 1 was efficiently radiolabeled (> $90 \%$ ) with ${ }^{111}$ In and ${ }^{67} \mathrm{Ga}$ within 30 $\min$ (Fig. 2A and 2B, respectively). The radiolabeling of the DOTA-GA conjugate 4 with ${ }^{203} \mathrm{~Pb}$ was equally efficient (Fig. 2C). Non-radioactive $\mathrm{Ga}(\mathrm{III})-\mathbf{1}$ and $\mathrm{Pb}(\mathrm{II})-\mathbf{4}$ were also synthesized in order to characterize the radiolabeled ${ }^{67} \mathrm{Ga}$ and ${ }^{203} \mathrm{~Pb}$ complexes. ${ }^{25}, 26$ Figures 3 and 4 demonstrate HPLC profiles of the mixture containing both $\mathrm{Ga}(\mathrm{III})-\mathbf{1}$ and ${ }^{67} \mathrm{Ga}-\mathbf{1}$; and $\mathrm{Pb}(\mathrm{II})-\mathbf{4}$ and ${ }^{203} \mathrm{~Pb}-\mathbf{4}$, respectively.

A radioimmunoassay was performed to assess the binding ability of the radiolabeled NODA-GA and DOTA-GA conjugates with $\alpha_{\mathrm{v}} \beta_{3}$ integrin. The ${ }^{111}$ In-labeled $\mathbf{1}\left(2 \times 10^{6}\right.$ cpm, $0.47 \mu \mathrm{M}),{ }^{67} \mathrm{Ga}$-labeled $\mathbf{1}\left(5 \times 10^{5} \mathrm{cpm}, 0.45 \mu \mathrm{M}\right)$ or ${ }^{203} \mathrm{~Pb}$-labeled $\mathbf{4}\left(3 \times 10^{5} \mathrm{cpm}\right.$, $0.5 \mu \mathrm{M}$ ) was incubated with $0,0.5,1.0$ and $2.0 \mu \mathrm{M}$ of purified human $\mathrm{a}_{\mathrm{v}} \beta_{3}$ integrin (MW $237,000)$ in a total volume of $25 \mu \mathrm{L}$ PBS for $3 \mathrm{~h}$ at $37^{\circ} \mathrm{C}$. For non-specific binding, excess IAC $(20 \mu \mathrm{M})$ was added to the reaction mixture to block binding. The reaction mixture was then separated on a $10 \mathrm{~mL}$ Sephadex G50 column using PBS as eluent. Fractions $(0.5 \mathrm{~mL})$ were collected and subsequently counted in a $\gamma$-counter. As indicated in Table 1 , the labeled conjugates bound the integrin to varying degrees. The binding of ${ }^{111} \mathrm{In}-\mathbf{1}$ was greatest followed by ${ }^{67} \mathrm{Ga}-1$ and then ${ }^{203} \mathrm{~Pb}-4$. In addition, binding was blocked $~ 95 \%$ by the addition of a 10 to 20 -fold molar excess of the cold IAC to the reaction solution indicating specific binding of the labeled conjugates. Furthermore, it is worth noting that the reactivity of the ${ }^{111} \mathrm{In}-\mathbf{1}$ with $\mathrm{a}_{\mathrm{v}} \beta_{3}$ integrin $(88 \%)$ is higher than that reported for ${ }^{111}$ In-DOTA-IAC $(72 \%)^{7}$

In conclusion, the peptidomimetic $\alpha_{\mathrm{v}} \beta_{3}$ integrin antagonist (IAC) was conjugated to NODA-GA and DOTA-GA and successfully radiolabeled with ${ }^{111} \mathrm{In},{ }^{67} \mathrm{Ga}$ and ${ }^{203} \mathrm{~Pb}$. This promising preliminary data is fueling further investigation of NODA-GA-IAC and DOTAGA-IAC conjugates for targeting tumor associated angiogenesis and $a_{v} \beta_{3}$ integrin positive tumors using PET and SPECT imaging. Other potential applications include the use of radionuclides such as ${ }^{90} \mathrm{Y},{ }^{177} \mathrm{Lu}$ and ${ }^{212} \mathrm{~Pb}$ for radiotherapy.

\section{Supplementary Material}

Refer to Web version on PubMed Central for supplementary material.

\section{Acknowledgments}

This research was supported by the Intramural Research Program of the NIH, National Cancer Institute, Center for Cancer Research. 


\section{References and notes}

1. Takagi J, Springer RA. Immunol. Rev. 2002; 186:141. [PubMed: 12234369]

2. Haubner R, Wester HJ, Burkhart F, Senekowitsch-Schmidtke R, Weber W, Goodman SL, Kessler H, Schwaiger M. J. Nucl. Med. 2001; 42:326. [PubMed: 11216533]

3. Haubner R, Wester HJ, Weber WA, Mang C, Ziegler SI, Goodman SL, Senekowitsch-Schmidtke R, Kessler H, Schwaiger M. Cancer Res. 2001; 61:1781. [PubMed: 11280722]

4. von Hagen PM, Breeman WAP, Bernard HF, Schaar M, Mooij CM, Srinivasan A, Schmidt MA, Krenning EP, de Jong M. Int. J. Cancer. 2000; 8:186.

5. Hood JD, Bednarski M, Frausto R, Guccione S, Reisfeld RA, Xiang R, Cheresh DA. Science. 2002; 296:2402.

6. Burnett CA, Xie J, Quijano J, Shen Z, Hunter F, Bur M, Li KCP. Bioorg. Med. Chem. 2005; 13:3763. [PubMed: 15863003]

7. Jang BS, Lim E, Park SH, Shin IS, Danthi SN, Hwang IS, Le N, Yu S, Xie J, Li KCP, Carrasquillo JA, Paik CH. Nucl. Med. Biol. 2007; 34:363. [PubMed: 17499725]

8. Ikotun OF, Lapi SE. Future Med. Chem. 2011; 3:599. [PubMed: 21526898]

9. Wadas TJ, Wong EH, Weisman GR, Anderson CJ. Chem. Rev. 2010; 110:2858. [PubMed: 20415480]

10. Meyer GJ, Macke HR, Schuhmacher J, Knapp WH, Hoffman TJ. Eur. J. Nucl. Med. Mol. Imaging. 2004; 31:1097. [PubMed: 15029459]

11. Craig AS, Helps IM, Jankowski KJ, Parker D, Beeley NRA, Boyce BA, Eaton MAW, Millican AT, Millar K, Phipps A, Rhind SK, Harrison A, Walker C. J. Chem. Soc., Chem. Commun. 1989:794.

12. Knetsch PA, Petrik M, Griessinger CM, Rangger C, Fani M, Kesenheimer C, von Guggenberg E, Pichler BJ, Virgolini I, Decristoforo C, Haubner R. Eur. J. Nucl. Med. Mol. Imaging. 2011; 28:1303. [PubMed: 21487838]

13. Kumar K, Magerstaedt M, Gansow OA. J. Chem. Soc., Chem. Commun. 1989; 3:145.

14. Ruegg CL, Anderson-Berg WT, Brechbiel MW, Mirzadeh S, Gansow OA, Strand M. Cancer Res. 1990; 50:4221. [PubMed: 2364380]

15. Mirzadeh S, Kumar K, Gansow OA. Radiochim. Acta. 1993; 60:1.

16. Pippin CG, McMurray TJ, Brechbiel MW, McDonald M, Lambrecht R, Milenic DM, Roselli M, Colcher D, Gansow OA. Inorg. Chim. Acta. 1995; 239:43.

17. Milenic DE, Roselli M, Brechbiel MW, Pippin CG, McMurry TJ, Carrasquillo JA, Colcher D, Lambrecht R, Gansow OA, Schlom J. Eur. J. Nucl. Med. 1998; 25:471. [PubMed: 9575242]

18. Chappell LL, Dadachova E, Milenic DE, Garmestani K, Wu C, Brechbiel MW. Nucl. Med. Biol. 2000; 27:93. [PubMed: 10755652]

19. Garmestani K, Milenic DE, Brady ED, Plascjak PS, Brechbiel MW. Nucl. Med. Biol. 2005:301. [PubMed: 15820766]

20. Chong H-S, Milenic DE, Garmestani K, Brady ED, Arora H, Pfiester C, Brechbiel MW. Nucl. Med. Biol. 2006:459. [PubMed: 16720237]

21. Miao Y, Figueroa SD, Fisher DR, Moore HA, Testa RF, Hoffman TJ, Quinn TP. J. Nucl. Med. 2008; 49:823. [PubMed: 18413404]

22. Eisenwiener K-P, Powell P, Mäcke HR. Bioorg. Med. Chem. Lett. 2000; 10:2133. [PubMed: 10999487]

23. ${ }^{1} \mathrm{H}$ NMR $\left(\mathrm{D}_{2} \mathrm{O}\right) \delta 0.90(\mathrm{~s}, 6 \mathrm{H}), 1.82(\mathrm{br}, 2 \mathrm{H}), 2.00(\mathrm{~m}, 2 \mathrm{H}), 2.39(\mathrm{br} \mathrm{t}, 2 \mathrm{H}), 2.9-3.4(\mathrm{~m}, 20 \mathrm{H})$, $349(\mathrm{~m}, 6 \mathrm{H}), 3.53(\mathrm{~m}, 2 \mathrm{H}), 3.80(\mathrm{~m}, 3 \mathrm{H}), 3.88(\mathrm{br} \mathrm{s}, 2 \mathrm{H}), 4.15(\mathrm{br}, 2 \mathrm{H}), 4.34(\mathrm{br} \mathrm{t}, \mathrm{J}=6.0 \mathrm{~Hz}, 1 \mathrm{H})$, $6.95(\mathrm{~d}, \mathrm{~J}=8.1 \mathrm{~Hz}, 2 \mathrm{H}), 7.74(\mathrm{~d}, \mathrm{~J}=8.1 \mathrm{~Hz}, 2 \mathrm{H}) .{ }^{13} \mathrm{C} \mathrm{NMR}\left(\mathrm{D}_{2} \mathrm{O}\right) \delta$ 14.2, 19.8, 35.1, 39.0, 40.4, 51.7, 66.2, 67.1, 114.5, 121.2, 129.5, 153.8. ESI-MS: $m / z=943.3$ for $[\mathrm{M}+\mathrm{H}]^{+}, 472.2$ for $[\mathrm{M}+$ $2 \mathrm{H}]^{2+}\left(943.03\right.$ calcd. for $\left.\mathrm{C}_{39} \mathrm{H}_{62} \mathrm{~N}_{10} \mathrm{O}_{15} \mathrm{~S}\right)$. Anal. Calcd. for $\mathrm{C}_{39} \mathrm{H}_{62} \mathrm{~N}_{10} \mathrm{O}_{15} \mathrm{~S}(\mathrm{TFA})_{2}\left(\mathrm{H}_{2} \mathrm{O}\right)$ : C 43.43; H 5.59; N 11.77; S 2.61; Found: C 43.56; H 5.69; N 11.08; S 2.61.

24. ESI-MS: $m / z=1042.3$ for $[\mathrm{M}-\mathrm{H}]^{-}\left(1043.46\right.$ calcd. for $\left.\mathrm{C}_{43} \mathrm{H}_{69} \mathrm{O}_{17} \mathrm{~S}\right)$.

25. ESI-MS: $m / z=1009.2$ for $[\mathrm{M}+\mathrm{H}]^{+}, 506.0$ for $[\mathrm{M}+2 \mathrm{H}]^{2+}(1008.31$ calcd. for $\left.\mathrm{C}_{39} \mathrm{H}_{59} \mathrm{~N}_{10} \mathrm{O}_{15} \mathrm{SGa}\right)$ 
26. ESI-MS: $m / z=1248.3$ for $[\mathrm{M}+\mathrm{H}]^{+}\left(1247.50\right.$ calcd. for $\left.\mathrm{C}_{43} \mathrm{H}_{65} \mathrm{~N}_{11} \mathrm{O}_{17} \mathrm{SPb}\right)$ 


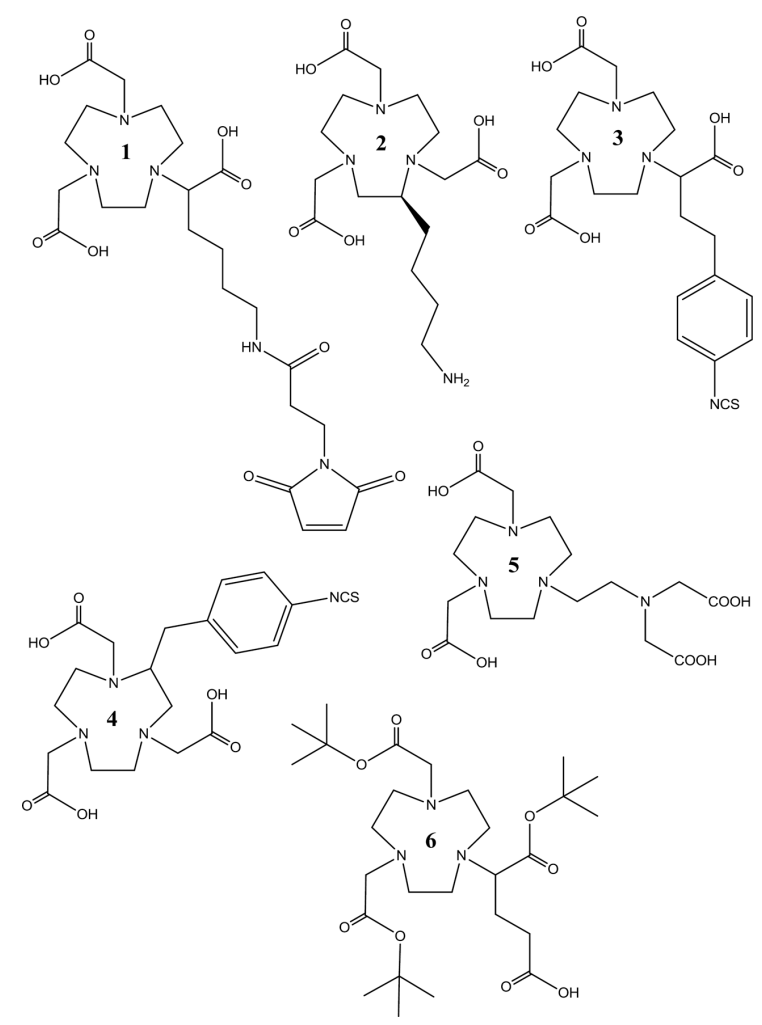

Figure 1.

Structures of NOTA derivatives. 7-(5-Maleimido-1-ethoxycarbonylphenyl)-1,4,7-

triazacyclononane-1,4-diylacetic acid (1), 2-(4-Aminobutyl)-1,4,7-triazacyclononane-1,4,7triyltriacetic acid (2), nNOTA (3), $p$-SCN-Bn-NOTA (4), NETA (5), and NODA-GA( $t \mathrm{Bu})_{3}$ (6). 
A

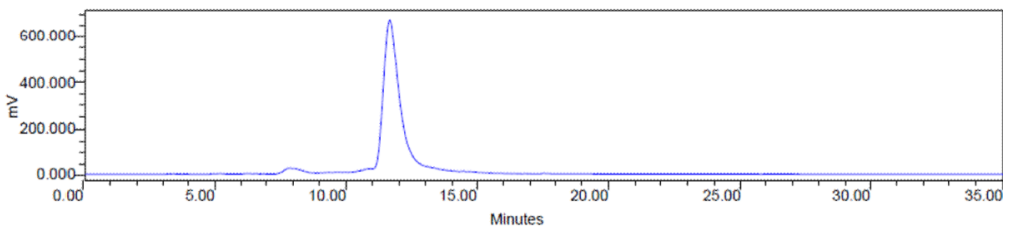

B

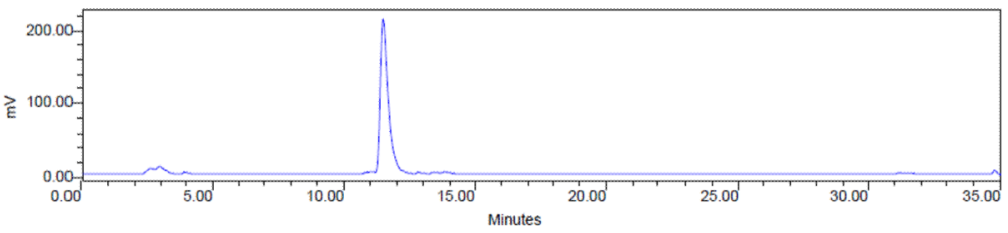

C

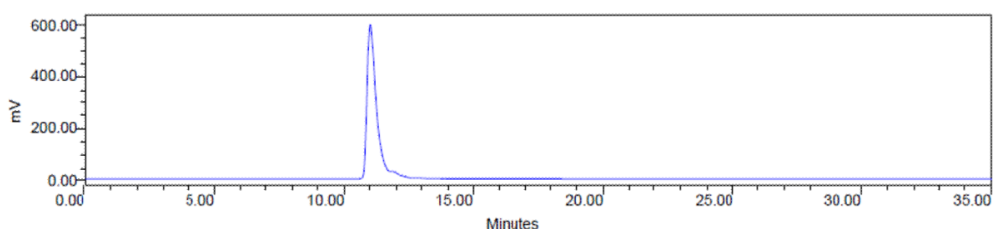

Figure 2.

Radio-HPLC profiles of ${ }^{111} \mathrm{In}-\mathbf{1}, \mathbf{A} ;{ }^{67} \mathrm{Ga}-\mathbf{1}, \mathbf{B}$; and ${ }^{203} \mathrm{~Pb}-\mathbf{4}, \mathbf{C}$ and 


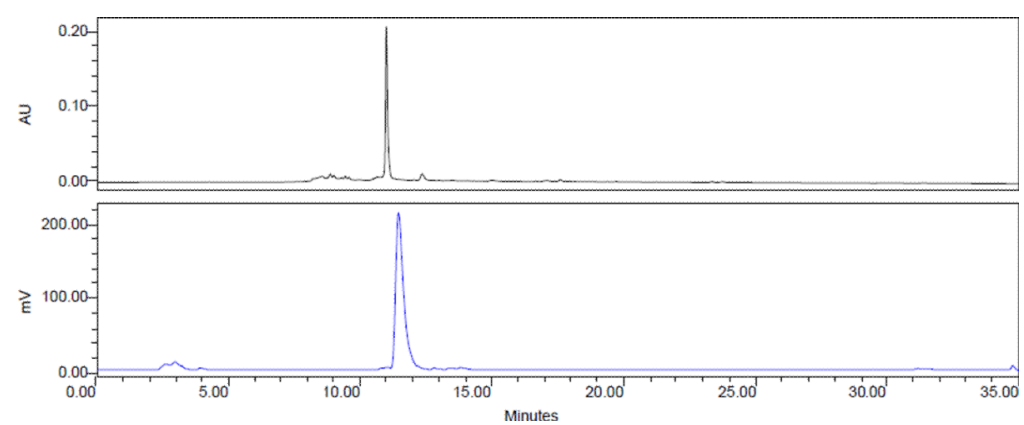

Figure 3.

HPLC profiles of $\mathrm{Ga}(\mathrm{III})-\mathbf{1}$ (top) and ${ }^{67} \mathrm{Ga}-\mathbf{1}$ (bottom) 


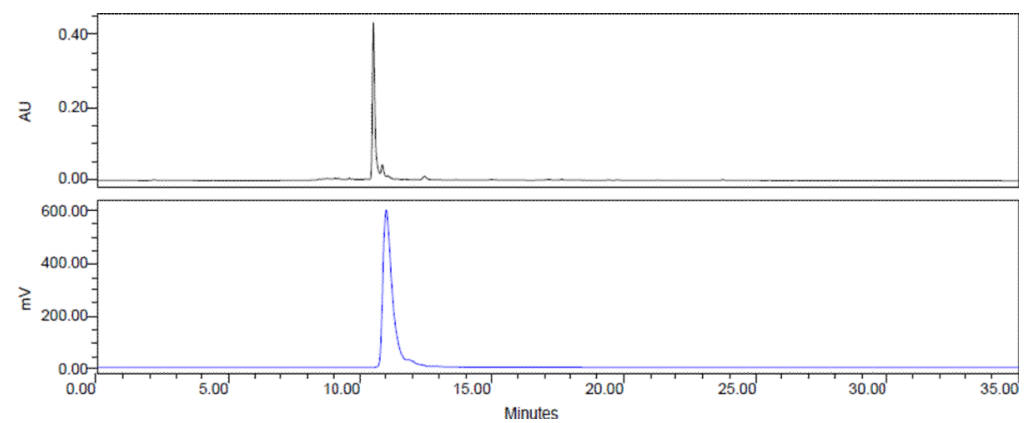

Figure 4.

HPLC profiles of $\mathrm{Pb}(\mathrm{II})-4$ (top) and ${ }^{203} \mathrm{~Pb}-4$ (bottom). 

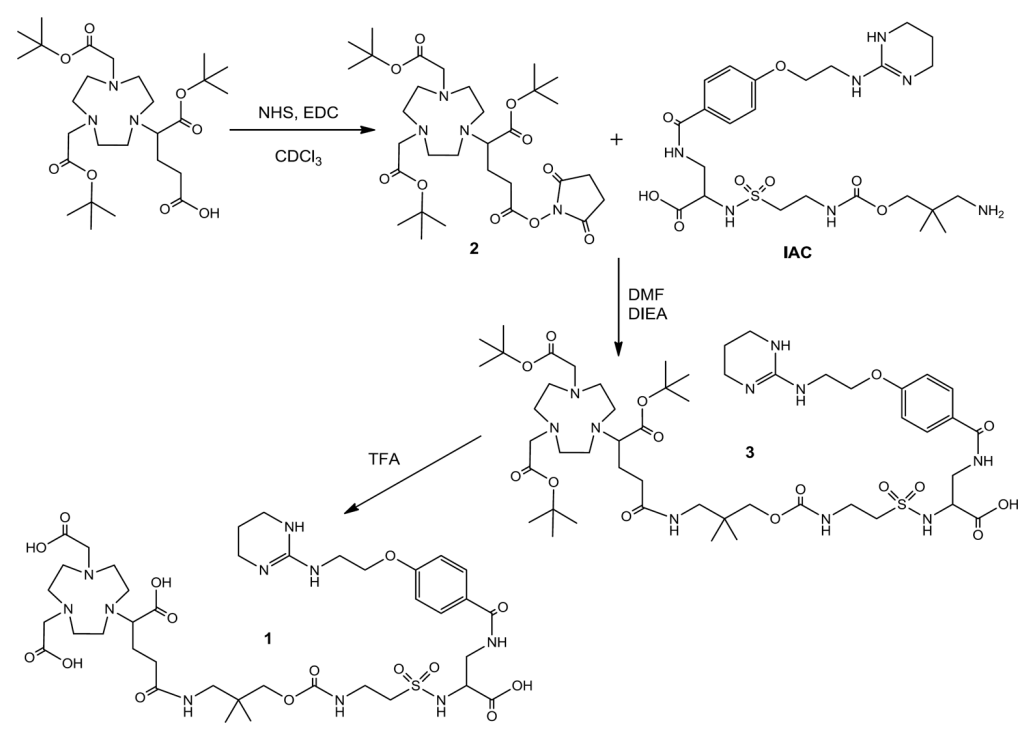

Scheme 1.

Synthesis of compound $\mathbf{1}$. 

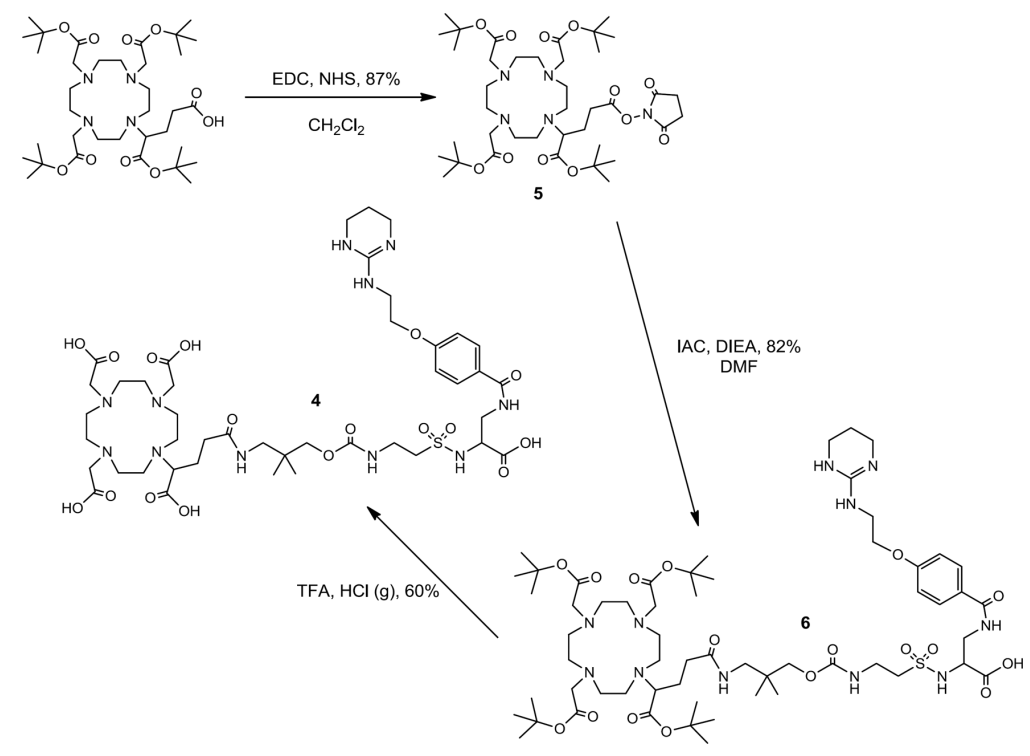

Scheme 2.

Synthesis of compound $\mathbf{4}$. 
Table 1

Binding of ${ }^{111} \mathrm{In}-\mathbf{1},{ }^{67} \mathrm{Ga}-\mathbf{1}$ and ${ }^{203} \mathrm{~Pb}-\mathbf{4}$ to purified $\mathrm{a}_{\mathrm{v}} \beta_{3}$ integrin.

\begin{tabular}{lc}
\hline & Bound (\%) \\
No Integrin $\left({ }^{111} \mathrm{In}-\mathbf{1}\right.$ Only $)$ & 5.3 \\
$0.5 \mu \mathrm{M}$ Integrin $+{ }^{111} \mathrm{In}-\mathbf{1}(0.47 \mu \mathrm{M})$ & 66.0 \\
$1 \mu \mathrm{M}$ Integrin $+{ }^{111} \mathrm{In}-\mathbf{1}(0.47 \mu \mathrm{M})$ & 88.1 \\
$1 \mu \mathrm{M}$ Integrin $+{ }^{111} \mathrm{In}-\mathbf{1}+\mathrm{IAC}(20 \mu \mathrm{M})$ & 5.4 \\
\hline & $\underline{\text { Bound (\%) }}$ \\
No Integrin $\left({ }^{67} \mathrm{Ga}-\mathbf{1}\right.$ Only $)$ & 2.1 \\
$0.5 \mu \mathrm{M}$ Integrin $+{ }^{67} \mathrm{Ga}-\mathbf{1}(0.45 \mu \mathrm{M})$ & 10.7 \\
$1 \mu \mathrm{M}$ Integrin $+{ }^{67} \mathrm{Ga}-\mathbf{1}(0.45 \mu \mathrm{M})$ & 25.5 \\
$2 \mu \mathrm{M}$ Integrin $+{ }^{67} \mathrm{Ga}-\mathbf{1}(0.45 \mu \mathrm{M})$ & 43.6 \\
$2 \mu \mathrm{M}$ Integrin $+{ }^{67} \mathrm{Ga}-\mathbf{1}+\mathrm{IAC}(20 \mu \mathrm{M})$ & 1.6 \\
\hline & $\underline{\text { Bound }(\boldsymbol{\%})}$ \\
\hline No Integrin $\left({ }^{203} \mathrm{~Pb}-\mathbf{4}\right.$ Only $)$ & 0.3 \\
$0.5 \mu \mathrm{M}$ Integrin $+{ }^{203} \mathrm{~Pb}-\mathbf{4}(0.5 \mu \mathrm{M})$ & 10.9 \\
$1 \mu \mathrm{M}$ Integrin $+{ }^{203} \mathrm{~Pb}-\mathbf{4}(0.5 \mu \mathrm{M})$ & 20.0 \\
$2 \mu \mathrm{M}$ Integrin $+{ }^{203} \mathrm{~Pb}-\mathbf{4}(0.5 \mu \mathrm{M})$ & 33.4 \\
$2 \mu \mathrm{M}$ Integrin $+{ }^{203} \mathrm{~Pb}-\mathbf{4}+\mathrm{IAC}(20 \mu \mathrm{M})$ & 0.3 \\
\hline
\end{tabular}

